\title{
Communication
}

\section{Electrocoagulation Process: Achievements and Green Perspectives}

\author{
Djamel Ghernaout ${ }^{1,2,3}$ \\ ${ }^{1}$ Chemical Engineering Department, College of Engineering, University of Ha'il, Ha'il, Saudi Arabia \\ ${ }^{2}$ Binladin Research Chair on Quality and Productivity Improvement in the Construction Industry, College of Engineering, University of Ha'il, \\ Ha'il, Saudi Arabia \\ ${ }^{3}$ Chemical Engineering Department, Faculty of Engineering, University of Blida, Blida, Algeria
}

Email address:

djamel_andalus@hotmail.com

To cite this article:

Djamel Ghernaout. Electrocoagulation Process: Achievements and Green Perspectives. Colloid and Surface Science. Vol. 3, No. 1, 2018, pp. 1-5. doi: 10.11648/j.css.20180301.11

Received: January 25, 2018; Accepted: February 5, 2018; Published: March 2, 2018

\begin{abstract}
This short communication concerns the author's proper brief story about performing research on electrocoagulation (EC) process. The main personal works performed on EC process are shortly introduced. For more than twenty years, working on EC technique still attract my interests due to the several advantages well-known of this electrochemical manner in treating water/wastewater in terms of killing microorganisms and organic matter removal. In spite of the great progress achieved in EC process application, more research remains required to reach a high level of industrial satisfaction. Humankind future quality is highly dependent on preserving nature from more polluting disasters and treating wastewater for drinking water direct use objectives.
\end{abstract}

Keywords: Electrocoagulation (EC), Electrochemical Disinfection, Magnetic Field (MF), Humic Acid (HA), Organic Matter Removal, Green Chemistry, Water Reuse (WR), Reverse Osmosis (RO)

\section{Introduction}

Writing a brief story about EC process and me is an ancient idea. During my research project performed for Chemical Engineer diploma preparation in 1992/1993, I worked on coagulation of humic acid (HA) in fluidized bed. For my Magister diploma research, in 1995/1996, I was asked to prepare inorganic membranes for microfiltration process using bentonite. The idea here was to build bentonite membranes. My entire story with EC process started at this moment. After my literature review, I understood that bentonite is constituted from metallic and negative layers that are separated with some gaps. These interfoliar distances may contain some positive ions. These bentonite electrostatic characteristics attracted my attention to use electrochemical techniques in order to purify bentonite suspension from its undesirable ions before the preparation of bentonite membranes. Performing simple electrochemical experiments using anode, cathode, and direct current (DC) power supply application in a beaker containing bentonite suspension was my first encounter with what we called, in our Laboratory, latter starting from 1996, EC process. These experiments were performed at the period where Internet was not yet known at all in my country, Algeria, and recent specialized books and papers focusing on electrochemical technologies were not yet at our reach. With my students, we worked on bentonite suspension [1] and HA solution. I also compared between conventional coagulation and EC. During my $\mathrm{PhD}$ preparation, I worked on microorganisms' removal [2]. All the following researches [3-28] are the consequences of the previous steps.

On the other hand, charge neutralization, as the main mechanism in classical coagulation, contributed to focus my attention on the electrochemical processes. Indeed, during my Engineer stage, I understood that for HA removal by coagulation using fluidized bed, charge neutralization is the key mechanism. In other words, an efficient coagulation process is highly dependent on charge neutralization before sweep coagulation step. During 1993-1997 period, my found results in coagulation process applications were supported by what the United States Environmental Protection Agency 
(USEPA) called "enhanced coagulation" [4].

Conventional water technology implies chemical products injection into raw water. This chemical therapy has several disadvantages such as chemicals toxicity and disinfection by-products (DBPs) formation. These issues pushed me to focus on green technologies $[13,14,19]$ for water treatment.

In the following Sections, a brief review on applying EC as an electrochemical killing microorganism's technique is given Moreover, a short abstract on using EC process coupled with magnetic field (MF) application for organic matter removal is presented.

\section{Applying EC in Escherichia coli Culture and Two Surface Waters}

Laboratory experiments were carried out to investigate EC as an electrodisinfection of artificial wastewater contaminated by no pathogenic Escherichia coli species in batch culture and two surface waters using three different electrodes. Aluminum electrodes were found most efficient in $E$. coli cells destruction comparatively with stainless steel and ordinary steel. Only thirty minutes are required for EC to achieve total E. coli cells removal (Figure 1). EC has shown the same efficiency toward algae and coliforms in two kinds of surface waters. The main mechanisms of EC are charge neutralization of microorganisms by electrical field and metallic cations followed by their flotation or sedimentation.

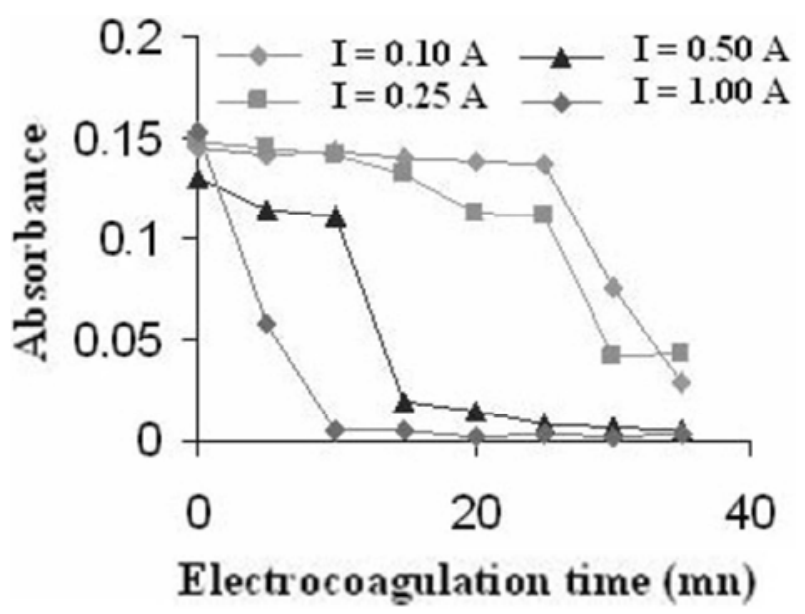

Figure 1. Reduction of cellular concentration of E. coli as a function of current density using ordinary steel electrodes during $t_{E C}=35 \mathrm{~min}$ [2].

\section{Microorganisms' Electrochemical Disinfection Phenomena}

Regardless of the reality that the deactivation of bacteria by different electrochemical disinfection means has been largely reported in the literature, the influence of process variables and reactor conception on kill performance has not been well comprehended [28]. Moreover, a small number of researches focused on the mechanisms of EC disinfection. In my recent review [28], I focused on electrochemical microbial killing mechanisms. Several related and pertinent references are examined and key mechanisms are revealed. Some mechanisms have been suggested to interpret the deadliness of electrochemical application, comprising (1) oxidative stress and cell loss of life because of electrochemically produced oxidants, (2) irreversible permeabilization of cell membranes by the placed electric field, (3) electrochemical oxidation of vital cellular constituents during exposure to electric current or induced electric fields, and (4) electrosorption of negatively charged microorganisms cells to the anode surface followed by direct electron transfer reaction (Figure 2) [28].

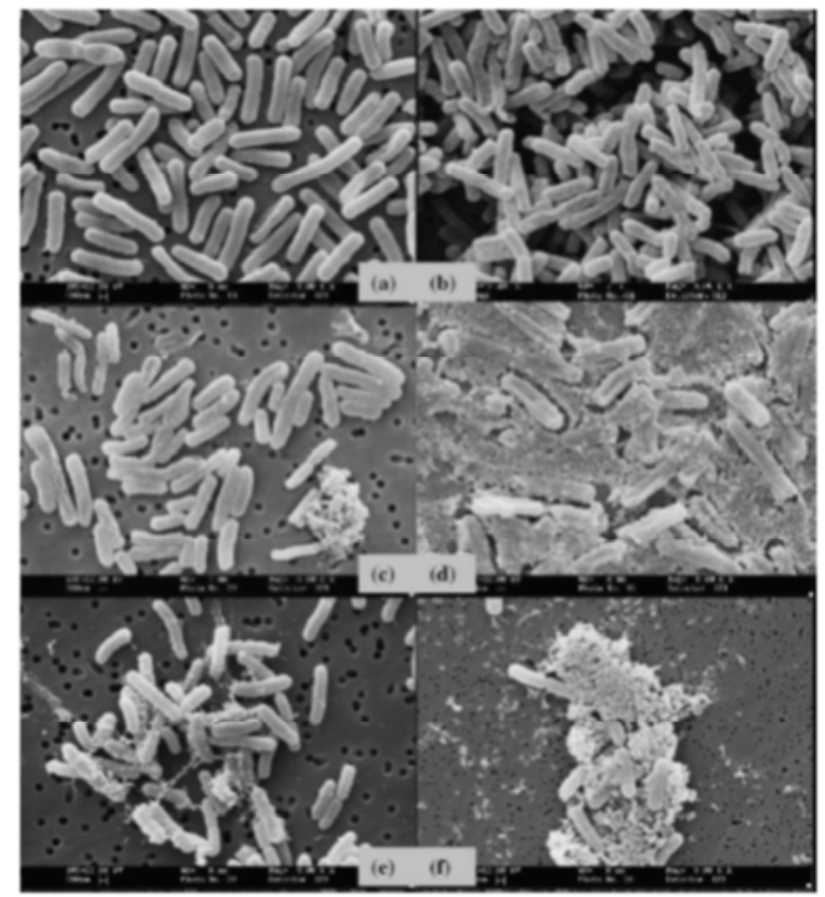

Figure 2. Scanning electron microscopy (SEM) photographs of E. coli cells in (a) fresh culture and after (b) chlorination at $5 \mathrm{mg} / \mathrm{L}$ for $30 \mathrm{~min}$, (c) ozonation at $10 \mathrm{mg} / \mathrm{L}$ for $5 \mathrm{~min}$, (d) the Fenton reaction with $8.5 \mathrm{mg} / \mathrm{L} \mathrm{H}_{2} \mathrm{O}_{2}$ and 0.85 $\mathrm{mg} / \mathrm{L} \mathrm{Fe}^{2+}$ at $\mathrm{pH} 4$ for $10 \mathrm{~min}$, (e) electrochemical disinfection at $16 \mathrm{~mA} / \mathrm{cm}^{2}$ for 2 min and (f) electrochemical disinfection at $25 \mathrm{~mA} / \mathrm{cm}^{2}$ for $2 \mathrm{~min}$ [28].

\section{Decolorization of Methyl Orange (MO) by EC Using Fe Electrodes Under a Magnetic Field (MF)}

In our recent work [29], we treated the decolorization of methyl orange (MO) by the EC method with application of a magnetic field (MF) (EC-MF) (Figure 3). Experimentally, the electrochemical cell consisted of two iron electrodes, which were kept at $2 \mathrm{~cm}$ with an active surface of $12.5 \mathrm{~cm}^{2}$. The main experimental parameters, including supporting electrolyte, current density, $\mathrm{pH}$ and $\mathrm{MO}$ concentration, were optimized. After $12 \mathrm{~min}$, the rate of MO decolorization by EC-MF reached its maximum (95\%) which is higher than that obtained with EC (74\%) at $\mathrm{pH} 7.25$ with a current density of $64 \mathrm{~A} / \mathrm{m}^{2}$. The XRD analysis proved the presence of hematite $\mathrm{Fe}_{2} \mathrm{O}_{3}$ in the formed flocs. 


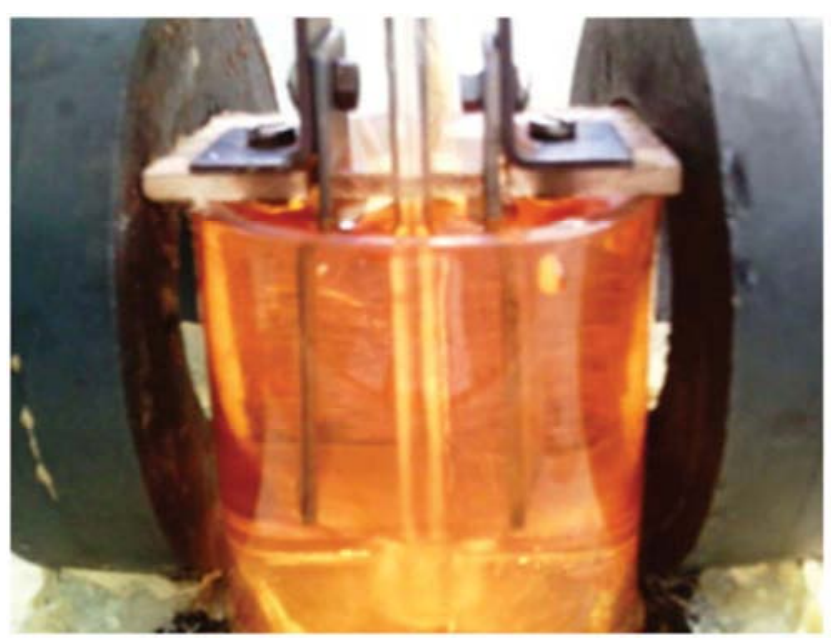

Figure 3. The apparatus of EC with MF magnets placed for the treatment of MO [29].

The SEM/energy disperses X-ray (EDX) analysis confirmed the presence of iron and oxygen in the flocs (Figure 4). The removal mechanism suggested that $\mathrm{MO}$ be reduced to sulfanilic acid and 2-naphtol. The energy consumption was decreased from 28 to $19 \mathrm{kWh} / \mathrm{kg}$ of $\mathrm{MO}$, for EC process and EC-MF, respectively.
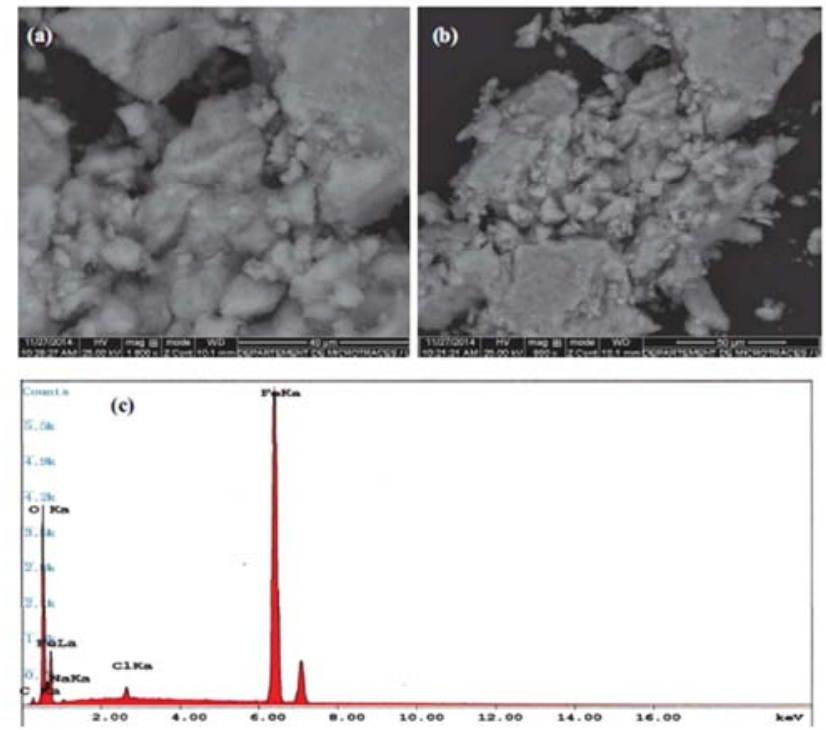

Figure 4. SEM ((a) and (b)) and EDX (c) of the flocs generated by EC with application of the $M F$ process with optimum conditions $\left(C_{M O}=15 \mathrm{mg} / \mathrm{L}, C_{\mathrm{NaCl}}\right.$ $=1.6 \mathrm{~g} / \mathrm{L}, M F=0.1 \mathrm{~T}, \mathrm{~J}=64 \mathrm{~A} / \mathrm{m}^{2}, d=2 \mathrm{~cm}, t_{E C}=30 \mathrm{~min}, \mathrm{pH}=7.25$ ) [29].

The obtained results depicted that the application of the MF in the EC process is one of the most promising methods of increasing removal efficiency, accentuating process compactness and lowering energy consumption. More research is still needed to open the process of industrial application perspectives (Figure 5).

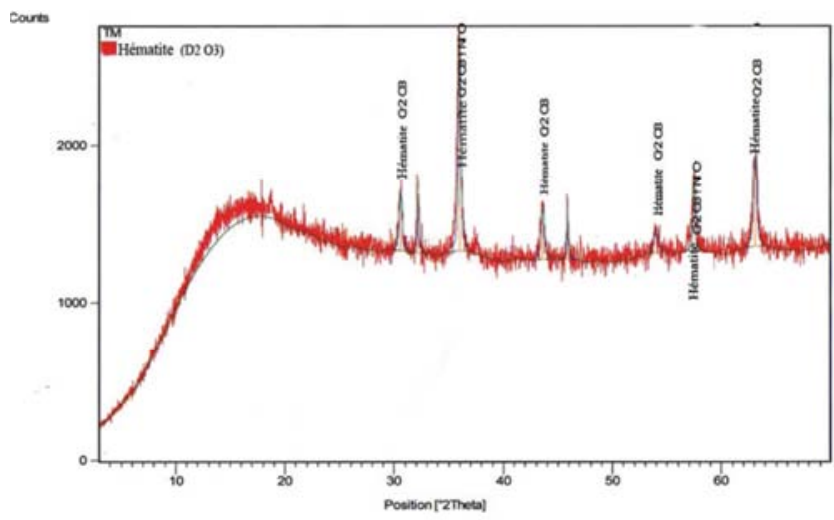

Figure 5. XRD of the flocs generated by EC-MF process at the optimum conditions $\left(C_{M O}=15 \mathrm{mg} / \mathrm{L}, C_{\mathrm{NaCl}}=1.6 \mathrm{~g} / \mathrm{L}, \mathrm{MF}=0.1 \mathrm{~T}, \mathrm{~J}=64 \mathrm{~A} / \mathrm{m}^{2}, d=2 \mathrm{~cm}\right.$, $\left.t_{E C}=30 \min , p H=7.25\right)$ [29].

\section{Applying EC in Water Reuse (WR) Perspective}

There is no doubt that the humankind is urgently invited to make available for potable use satisfactory quantities of good quality water to its increasing population [30]. There is a big effort by the water treatment specialists to analyze the solutions the humankind has at its disposition to respond to these risks [31]. The contribution of water reuse (WR) would be great in the humankind's water tomorrow. WR is broadly applied by industries to decrease the consumption of clean water. WR process should employ treated wastewater mixed with surface water at a certain proportion depending on the degree of purity of the treated water and assuring the dilution effect. WR should not employ at any case only wastewater, for safeguard reasons and psychological effects. WR should be obviously more sophisticated than both water treatment and wastewater treatment since pathogens contamination and chemicals presence can be there most elevated. Since pharmaceutical products and cosmetics substances at trace levels are found in tap water, should we assist to a new formulation of water treatment technology? This will be feasible if water treatment/wastewater treatment/WR would be merged in a super and highly standardized water/wastewater treatment technology, as a future trend [30].

EC process would find its appropriate place in WR treatment technology due to its numerous benefits as shown above in terms of pathogens killing and organic matter removal.

\section{Reverse Osmosis: A Viable and Green Technology}

Invented 60 years ago, reverse osmosis (RO) became a frequent unit operation in chemical and environmental engineering plants [32, 33]. Nowadays, this membrane process is occurring in a larger interval of industrial applications such as desalination of seawater and brackish water, treatment of municipal and industrial wastes, 
concentration of food products, production of ultra-pure water for several applications comprising the semi-conductor industry, and recovery of important materials in chemical and petrochemical industries $[32,33]$. RO is an interesting process since it is simple, it can be used for a wide interval of issues in diverse fields, it is economically competitive, and it needs no phase variation $[32,33]$. The last characteristic is especially crucial for solutions which are responsive to heating, such as food products and pharmaceutical materials [32, 33].

As a physical process, RO membranes would be better placed after EC process for better dissolved ions removal.

\section{Environmental Principles Perspectives}

Green chemistry $[13,14,19,34]$ is the key to sustainable development as it will lead to new solutions to existing problems. Moreover, it will present opportunities for new processes and products and at its heart is scientific and technological innovation. Following the establishment of the 12 Principles of GC, there has been a steady growth in our understanding of what GC means. Furthermore, there are great perspectives relating to the greening of chemical water treatment, especially in terms of ferrate(VI) [14] adding, as oxidant/disinfectant/coagulant in the same time, and microchannel reactors which would be considered as promising devices for water treatment due to their proved advantages.

\section{Conclusion}

Writing a brief view on my works performed on EC process is in fact writing about my proper life since I was implied in this research axis during these two decades. Discovering this electrochemical technique by scientific curiosity five years (in 1996) before the Internet and academic interests (in 2001) has given me some pride through.

In spite of the great progress achieved in EC process, more research remains required to reach a high level of industrial application perspectives.

Humankind future quality is highly dependent on preserving nature from more polluting disasters and treating wastewater for drinking water direct use objectives.

\section{References}

[1] D. Ghernaout, B. Ghernaout, A. Boucherit, Effect of $\mathrm{pH}$ on electrocoagulation of bentonite suspensions in batch using iron electrodes, J. Dispersion Sci. Technol. 29 (2008) 1272-1275.

[2] D. Ghernaout, A. Badis, B. Ghernaout, A. Kellil, Application of electrocoagulation in Escherichia coli Culture and two surface waters, Desalination 219 (2008) 118-125.

[3] D. Ghernaout, B. Ghernaout, A. Saiba, A. Boucherit, A. Kellil, Removal of humic acids by continuous electromagnetic treatment followed by electrocoagulation in batch using aluminium electrodes, Desalination 239 (2009) 295-308.

[4] D. Ghernaout, B. Ghernaout, A. Kellil, Natural organic matter removal and enhanced coagulation as a link between coagulation and electrocoagulation, Desalin. Water Treat. 2 (2009) 209-228.

[5] D. Ghernaout, B. Ghernaout, A. Boucherit, M. W. Naceur, A. Khelifa, A. Kellil, Study on mechanism of electrocoagulation with iron electrodes in idealised conditions and electrocoagulation of humic acids solution in batch using aluminium electrodes, Desalin. Water Treat. 8 (2009) 91-99.

[6] A. Saiba, S. Kourdali, B. Ghernaout, D. Ghernaout, In Desalination, from 1987 to 2009 , the birth of a new seawater pretreatment process: Electrocoagulation - An overview, Desalin. Water Treat. 16 (2010) 201-217.

[7] D. Ghernaout, B. Ghernaout, From chemical disinfection to electrodisinfection: The obligatory itinerary?, Desalin. Water Treat. 16 (2010) 156-175.

[8] D. Belhout, D. Ghernaout, S. Djezzar-Douakh, A. Kellil, Electrocoagulation of Ghrib Dam's water (Algeria) in batch using iron electrodes, Desalin. Water Treat. 16 (2010) 1-9.

[9] B. Ghernaout, D. Ghernaout, A. Saiba, Algae and cyanotoxins removal by coagulation/flocculation: A review, Desalin. Water Treat. 20 (2010) 133-143.

[10] D. Ghernaout, A. Mariche, B. Ghernaout, A. Kellil, Electromagnetic treatment-bi-electrocoagulation of humic acid in continuous mode using response surface method for its optimization and application on two surface waters, Desalin. Water Treat. 22 (2010) 311-329.

[11] D. Ghernaout, M. W. Naceur, A. Aouabed, On the dependence of chlorine by-products generated species formation of the electrode material and applied charge during electrochemical water treatment, Desalination 270 (2011) 9-22.

[12] D. Ghernaout, B. Ghernaout, On the controversial effect of sodium sulphate as supporting electrolyte on electrocoagulation process: A review, Desalin. Water Treat. 27 (2011) 243-254.

[13] D. Ghernaout, B. Ghernaout, M. W. Naceur, Embodying the chemical water treatment in the green chemistry - A review, Desalination 271 (2011) 1-10.

[14] D. Ghernaout, M. W. Naceur, Ferrate(VI): In situ generation and water treatment - A review, Desalin. Water Treat. 30 (2011) 319-332.

[15] D. Ghernaout, M. W. Naceur, B. Ghernaout, A review of electrocoagulation as a promising coagulation process for improved organic and inorganic matters removal by electrophoresis and electroflotation, Desalin. Water Treat. 28 (2011) 287-320.

[16] D. Ghernaout, B. Ghernaout, Sweep flocculation as a second form of charge neutralisation - A Review, Desalin. Water Treat. 44 (2012) 15-28.

[17] D. Ghernaout, B. Ghernaout, On the concept of the future drinking water treatment plant: Algae harvesting from the algal biomass for biodiesel production-A Review, Desalin. Water Treat. 49 (2012) 1-18.

[18] D. Ghernaout, Advanced oxidation phenomena in electrocoagulation process: A myth or a reality?, Desalin. Water Treat. 51 (2013) 7536-7554. 
[19] D. Ghernaout, The best available technology of water/wastewater treatment and seawater desalination: Simulation of the open sky seawater distillation, Green Sustain. Chem. 3 (2013) 68-88.

[20] D. Ghernaout, S. Irki, A. Boucherit, Removal of $\mathrm{Cu}^{2+}$ and $\mathrm{Cd}^{2+}$, and humic acid and phenol by electrocoagulation using iron electrodes, Desalin. Water Treat. 52 (2014) 3256-3270.

[21] D. Ghernaout, The hydrophilic/hydrophobic ratio vs. dissolved organics removal by coagulation - A review, J. King Saud Univ. - Sci. 26 (2014) 169-180.

[22] D. Ghernaout, C. Benblidia, F. Khemici, Microalgae removal from Ghrib Dam (Ain Defla, Algeria) water by electroflotation using stainless steel electrodes, Desalin. Water Treat. 54 (2015) 3328-3337.

[23] D. Ghernaout, S. Moulay, N. Ait Messaoudene, M. Aichouni, M. W. Naceur, A. Boucherit, Coagulation and chlorination of NOM and algae in water treatment: A review, Internat. J. Environ. Monitor. Analysis 2 (2014) 23-34.

[24] D. Ghernaout, A. I. Al-Ghonamy, M. W. Naceur, N. Ait Messaoudene, M. Aichouni, Influence of operating parameters on electrocoagulation of C. I. disperse yellow 3, J. Electrochem. Sci. Eng. 4 (2014) 271-283.

[25] D. Ghernaout, A. I. Al-Ghonamy, A. Boucherit, B. Ghernaout, M. W. Naceur, N. Ait Messaoudene, M. Aichouni, A. A. Mahjoubi, N. A. Elboughdiri, Brownian motion and coagulation process, American J. Environ. Protect. 4 (2015) $1-15$.

[26] D. Ghernaout, A. I. Al-Ghonamy, M. W. Naceur, A. Boucherit, N. Ait Messaoudene, M. Aichouni, A. A. Mahjoubi, N. A.
Elboughdiri, Controlling coagulation process: From Zeta potential to streaming potential, American J. Environ. Protect. 4 (2015) 16-27.

[27] D. Ghernaout, A. I. Al-Ghonamy, N. Ait Messaoudene, M. Aichouni, M. W. Naceur, F. Z. Benchelighem, A. Boucherit, Electrocoagulation of direct brown 2 (DB) and BF cibacete blue (CB) using aluminum electrodes, Sep. Sci. Technol. 50 (2015) 1413-1420.

[28] D. Ghernaout, Microorganisms' electrochemical disinfection phenomena, EC Microbiol. 9 (2017) 160-169.

[29] S. Irki, D. Ghernaout, M. W. Naceur, Decolourization of Methyl Orange (MO) by Electrocoagulation (EC) using iron electrodes under a magnetic field (MF), Desalin. Water Treat. 79 (2017) 368-377.

[30] D. Ghernaout, Water reuse (WR): The ultimate and vital solution for water supply issues, Intern. J. Sustain. Develop. Res. 3 (2017) 36-46.

[31] D. Ghernaout, Water treatment chlorination: An updated mechanistic insight review, Chem. Res. J. 2 (2017) 125-138.

[32] D. Ghernaout, A. El-Wakil, Requiring reverse osmosis membranes modifications - An overview, American J. Chem. Eng. 5 (2017) 81-88.

[33] D. Ghernaout, Reverse osmosis process membranes modeling - A historical overview, J. Civil Construct. Environ. Eng. Civil 2 (2017) 112-122.

[34] D. Ghernaout, Environmental principles in the Holy Koran and the Sayings of the Prophet Muhammad, American J. Environ. Protect. 6 (2017) 75-79. 